\title{
Rejoinder
}

\section{E. S. Hartland}

To cite this article: E. S. Hartland (1899) Rejoinder, Folklore, 10:1, 46-57, DOI:

10.1080/0015587X.1899.9720480

To link to this article: http://dx.doi.org/10.1080/0015587X.1899.9720480

曲 Published online: 14 Feb 2012.

Submit your article to this journal $2 \pi$

Q View related articles $₫$ 
at least a sketch of that kind in Mr. Brough Smyth's Aborigines of Victoria.

\section{Rejoinder.}

BY I. 5. HARTLAND.

The demolition of my criticisms has "taken such a deal of doing," that my rejoinder must, from considerations of space, be brief. Leaving minor issues, and avoiding as far as possible mere verbal discussions, therefore, 1 shall only touch on the principal points.

I note that Mr. Lang now adopts Professor Starr's statement of his case that "among" man's "earliest original conceptions is the idea of a kind, creative Supreme Being whom men may worship." This is a material variation from the hypothesis stated on p. 33 I of The Making of Religion, and quoted by me (Folklore, vol. ix., p. 293), that "there are two chief sources of religion: (I) the belief ... in a powerful, moral, eternal, omniscient Father and Judge of men; (2) the belief . . . in somewhat of man which may survive the grave," with the latter of which I was not dealing. The present statement is not only less definite, but it does not exclude other and contemporaneous religious beliefs. I cannot here examine the general question as to man's "earliest original conceptions" of deity, which is outside the issue I was debating, namely, the accuracy of $\mathrm{Mr}$. Lang's presentation of the "High Gods" of the Australians. It is the less necessary to do so, because Mr. Lang himself adopts the same phraseology with regard to the present Australians, contending "that the notion of a kind, creative Supreme Being is among the ideas of the Australians."

Mr. Lang admits that his use of rhetorical expressions was unwise, excusing himself, however, by saying that it was "partly a matter of capital letters and Latinised words." True, but by no means the whole truth. What is apt to mislead in The Making of Religion (all the latter half of it) is the choice of words associated with the theological concep- 
tions embodied in Christianity - nay, often the very words of the Bible-to express ideas far less definite, far more rudimentary, and not to be properly understood save in connection with the rest of the tribal and racial culture. When, for instance, we read of "Our Father" or the "Father in Heaven," we do not think of a one-legged being, or of a star, or of a giant sitting on an earthly mountain, rooted to the rock. When we are referred to "Leviticus, passim," in connection with a requirement to obey the food restrictions, we are apt to imagine that these restrictions have to do with chewing the cud, and parting the hoof, with the permanent distinction between clean and unclean animals, whereas they are merely tem. porary taboos for ritual reasons peculiar to the myths and ceremonies of the Australian natives, and having little or no analogy to the Hebrew prohibitions. If we want really to understand the religious ideas of savages, we ought to be specially careful to translate them into words uncoloured by our own theological connotations. When we have once got a clear conception of the savage's ideas (not an easy thing to do), we can then fairly estimate their analogies with and differences from our own. But it darkens knowledge to begin by using words which mean one thing to us and another thing to the savage, even if he attach any definite meaning to them at all.

This brings me to another source of misconception-the use of definite words for indefinite ideas. I need not labour the point as against Mr. Lang, since he admits its justice and amends his verbiage. But the expressions of his authorities continue to perplex him. Accordingly, I want to suggest to him that it is always wise to discount exact statements, by travellers and other observers, of ideas only vaguely apprehended by the savage mind. These exact statements arise partly from carelessness or misunderstanding, but partly also from the infirmities of language, partly too from the difficulty experienced by the civilised 
inquirer, be he traveller or missionary or whatever he may, in placing himself at the precise point of view of the lower culture. Mr. Lang sees it himself where the word spirit is concerned. Why does he not apply it to Creator and Creation, to Supreme Being, to immortal, and a score of other expressions used of savage religion at sundry times and by divers persons? Some of these expressions as used by himself he has admitted to be "rhetorical" or "overstrained." But the fact is that nothing is easier than to lay upon them a stress they will not bear, and to interpret them in a way that would indeed "astonish the natives." There are, I am persuaded, few students of savage life and religion who will not subscribe to the opinion that, from the time of Herodotus downwards, exaggerations and misstatements of this kind, unintentional and probably unavoidable, have been the source of innumerable baseless theorics; they have dug more pitfalls in the path of scientific research than any other class of causes.

Vagueness is one characteristic of the savage; inconsistency is another. Truly and wittily Mr. Frazer somewhere says: "Consistency is as little characteristic of savage as of civilised man." The savage, at all events, not only fails to define his ideas, even when they are more or less definite, he entertains others equally definite but contradictory, and he is at no pains to reconcile them one with another. Perhaps he is unconscious of the contradiction. Mr. Lang interprets the contradiction as the product of two human moods; and he calls one set of ideas religion and the other myths. This is of course a mere question of words. "This belief," he says, "I choose to call 'religious' because it conforms in its rude way to and is the germ of what we commonly style 'religion.'" Very well ; only let it be understood it is simply Mr. Lang's choice. Where both sets of ideas are equally and inextricably interwoven in the fabric of one and the same sequence of ceremonies, and those ceremonies are the most sacred rites of the tribe, it is hard to say that 


\section{Australian Gods: Rejoinder.}

one set is religious and the other not. It is hard to say, too, that one was afore or after other. In the evolution of the mysteries, what $\mathrm{Mr}$. Lang calls the myths may, for aught we know, have long preceded the appearance of what he calls religion. I do not say that they did, I simply put the possibility. But if they did, what becomes of Mr. Lang's hypothesis, even as revised by Professor Starr, that "among man's earliest conceptions" is the set of ideas qualified by Mr. Lang as "religious." It is no part of my argument to deny that man had upreaching desires, and longings which expressed themselves more or less definitely (but rather less than more) in what Mr. Lang calls " religious beliefs." What I deny is that they were more truly beliefs, or more religious, than what Mr. Lang calls myths. In his use of the word myths he illustrates the inconsistency of civilised man. Replying to me, he appears, in one place at least (see p. 15), to confine the meaning of the word to "obscene or humorous tales." Even then, I doubt whether myths are the result of "indulging " man's "fancy for fiction"-tales told consciously for amusement without any hold on serious belief. Some of them, perhaps, are; many of them certainly are not. In the passage he quotes just before from Myth, Ritual, and Religion, however, he seems to include other elements, notably " the irrational," which is not necessarily either obscene or humorous. And in The Making of Religion he speaks of the story about Mungan-ngaur's relation to the Kurnai as a myth-at least by implication, for he refers to " the opposite myth, of making or creating." Now Mungan-ngaur's relation to the Kurnai is precisely what Mr. Lang designates religion. Well may I ask: Where is the distinction?

Recognising, then, the co-existence of inconsistent beliefs, I find no difficulty in accepting both myths of Daramulun: that he died, and that he is "an anthropomorphic supernatural being," as part of the beliefs of the same tribes. I need hardly say that I never meant to suggest that Daramulun was literally the ghost of a man, but only that on the principle voL. $\mathbf{x}$. 
laid down by Mr. Lang he was "a confessed ghost-god." And I see no reason why the same tribes should not hold at the same time that he was on earth and died, and that he is living an anthropomorphic being in the sky. Similar beliefs coexisting about Zeus do not disturb Mr. Lang; nor need these. And perhaps they are reconcilable after all. ${ }^{1}$

Moreover, beliefs, though inconsistent in our judgment, are equally to be taken into consideration in estimating the conception formed by the savage of his god. One of my complaints of Mr. Lang's method is, that he has fixed his eyes too exclusively on one set of beliefs, turning away from the other as mere myths. Scientific investigation of the position of savage belief in the history of religion must take into account all the factors, giving due weight to them all. To assume that "the mythical element is secondary or aberrant," whether Darwin's view or not, is to assume the very question at issue. It is notoriously easy to prove anything by such a method. Mr. Lang is far too "sportsmanlike" (to adopt his phrase) for such a process, when it is once pointed out to him. And indeed the admissions that what he calls "the religion represents one human mood, while the myth repre. sents another, both moods dating from savagery," and that "of the same 'moral, relatively Supreme Being, or Creator,' man has simultaneously quite contradictory conceptions," involve a recognition of the justice of the criticism."

${ }^{1}$ In the passage on Daramulun (supra, p. 16) Mr. Lang speaks of Bunjil and Baiame as " translated." "Translated " is a large word to apply to Baiame. As applied to Bunjil, who was blown off the earth by an infuriated jay, it recalls the translation of Bottom.

3 Mr. Lang alleges that we have historical proof of the possilbility of degradation in the case of "the conception of God, in Christianity given pure, and then degraded in Aarchen" (p. 45). Anything like a discussion of this sulject would occupy much space, and would hardly be suitable for these pages. I think, however, I am relieved from it by the fact that between him and myself there is no dispute as to the priorities of ghost-worship and god-worship, properly so called, to which he applies it. But I may say that as at present advised, I cannot admit that the peasant populations of modern Europe, 
Mr. Lang's mind "broods fondly over" my remark that many expressions rhetorically used by him "convey to our minds reminiscences of Christian teaching of which the savage mind is guiltless." He interprets it as an assertion that, though under European influences, the Australian blackfellows are guiltless of Christian teaching, particularly with regard to Baiame. But it will be observed that the remark was a general protest against Mr. Lang's method of argument, and contained no affirmation respecting any specific race or belief. Hence, he cannot fasten upon me the charge of inconsistency in the mode of dealing with Baiame. My theory about Baiame is one that Mr. Lang quotes again and again, namely, that "the points of his story most resembling the Christian conception of Creator have been unconsciously evolved, first by white explorers, then by missionaries, and lastly by the natives themselves under European influence." Let me give an example of what I mean by the unconscious evolution by white explorers. I will take Mr. Manning's account, which I have had the opportunity of reading since my criticism was written. He was not, perhaps, literally an explorer, but an early settler. I have not space for the whole account, interesting and inportant though it be. Extracts will, however, show how Mr. Manning treated Baiame, or Boyma, as he writes the name. After describing him as "seated on a throne of

among whom the Marchen arose, ever had the lofty conception of the deity held by St. Paul or St. John, or consequently ever degraded it. They were on a differeni plane of civilisation and of thought from the writers of the New Testament, and I know of no evidence that they had ever been on the same plane. This is not at all a parallel case with that of the Australian savages, about whom we are arguing. Being all in a low stage of savagery, they hold "simulaneously quite contradictory canceptions," both sets of beliefs, the "religious" and the "mythical," as Mr. Lang chooses to call them. Which came first, he concedes, is mercly "surmise," for it cannot be historically proved. Ile thinks the "religious," or higher, set come first. That is his surmise-nothing more; and I venture to think the Europenn Mirchen yield it na countenance. 
transparent crystal of vast magnitude" with "a great many beautiful pillars of crystal, handsomely carved, and emitting prismatic colours," he says: "This description of the Godhead bears a striking resemblance to the description in the 3 rd verse of the $4^{\text {th }}$ chapter of Revelations (sic). They believe in the existence of a Son of God, equal with him in omniscience, and but slightly inferior to his Father in any attribute. Him they call 'Grogoragally.' His divine office is to watch over the actions of mankind, and to bring to life the dead to appear before the judgment-seat of his Father, who alone pronounces the awful judgment of eternal happiness in heaven ('Ballima') or eternal misery in 'Oorooma' (hell), which is a place of everlasting fire (gumby). . . . The Son watches the actions of men, and quickens the dead immediately upon their earthly interment. He acts as mediator for their souls to the great God, to whom the good and bad actions of all are known. . . He does not seem in their belief to be coequal with his Father; . . . his office seems chiefly to be to bring at the close of every day the spirits of the dead from all parts of the world to the judgment-seat of his Father, where alone there is eternal day. There he arts as intercessor for those who have only spent some portion of their lives in wickedness. Boyma, listening to the mediation of his Son, allows Grogorogally to admit some such into Ballima." 1 These extracts, given verbatim et literatim, disclose the attitude of Mr. Manning's mind. His phraseology, and even his capital letters, are chosen for the purpose of conveying to the reader's mind the elements of Christian theology, he thinks he has discovered in the beliefs of "the aborigines of New Holland." His mind was so imbued with Christian conceptions that probably he could not do otherwise. Anyhow, + is obvious that there is a great deal

'Journal of the Royal Society of New South Wales, vol. xvi., p. I59. Sydney, Thomas Richards, 1883 .

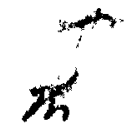


here to be discounted. Unless we discount liberally, the account is, in the language of $\mathrm{Mr}$. Lang's friend, "quite worthless." It is not an accurate scientific account. It is beyond doubt coloured and distorted. Mr. Manning has "unconsciously evolved" what he wormed out of his savage informant into a pale copy-caricature, if you please-of Christian ideas. He has presented us not with savage ideas, but with what he thinks they would be if expressed in the pompous and technical terms of Christian theologians. When he descends to particulars, he becomes more valuable. "Their belief in God's creation of His own Son was explained to me thus by the intelligent native from whom I derived my chief information. 'Boyma,' on his own creation, feeling lonesome, wished for a son after his own likeness." (Note here the capitals, the use of "God" for Boyma, the phrase "on his own creation," suggestive of a mild Arianism, and the phrase "after his own likeness.") "He observed in the firmament a liquid, resembling blood, which, reaching with his hand, he placed in a crystal oven, and in a short time the Son of God was born, a being resembling God and Man." Here, in spite of similar phraseology, we discover a myth familiar to Zulus and North American Indians, of which I have given examples elsewhere. If we had it entire, and in a form more like that in which it was really told, its true character would be still more apparent. I call it at all events a myth, and a very savage one. Mr. Lang does not quote it. I regret this, because it appears to be part of the sacred belief of the tribe referred to by $\mathrm{Mr}$. Manning, and it would be interesting to know whether Mr. Lang designates it as "myth " or "religion." If I had had Mr. Manning's Paper before me, I should not have said that Baiame's "biblical characteristics constantly expanded down to " 1878 . But that error does not affect the main question; and $\mathrm{Mr}$.

' Legend of Perseus, vol. i., The Supematual Birth, p. 97. 
Manning's version is an excellent example of the un. conscious evolution by white men of native ideas in a Christian direction, with which I have so sorely vexed the soul of Mr. Lang. Mr. Manning was not a missionary; but if he could not help colouring and distorting in a Christian direction, it is extremely likely that missionaries, whose minds were full of theological ideas and expressions, when they stumbled upon something in savage belief which bore a resemblance to these ideas (though a resemblance, it may be, superficial, or occasionally based on misunderstanding) would in expressing the story or belief in their own words unconsciously develop the resemblance they saw or fancied. But whether resemblances to Christian dogma be reported of savage belief by missionaries or other Europeans, I for one hesitate to admit them, until I have satisfied myself, not merely of the honesty (of that we need not ordinarily doubt) but of the competency of the witness-a competency not always to be measured simply by the length of time he has been in contact with the savage.

Oh! but, says Mr. Lang, "Mr. Manning's version of 1845 " is "much corroborated by Mrs. Langloh Parker in I 898." Well, I have not space to examine Mrs. Langloh Parker's version of the myth in detail : I must content myself with mentioning a few of the differences $I$ find in it. For her, Byamee is not "the God-head," but a man, "the mighty Wirreenun" (wizard or doctor), who has had a career on earth with other men, who has wives, one of whom shares his seat and has a will and powers of her own. In her account, "the Son of God" is not to be found, unless, as Mr. Lang suggests, in the solitary mysterious reference to "the All-seeing Spirit" who has nothing in her story to do with the judgement of the dead. According to her, Byamee has had two sons, but what has become of them does not appear; Bullimah, where he seems now to be, is bcyond the top of a mountain called Oobi Oobi, perhaps "one of the Noondoo ridges" (which I take to be an 
existing mountain-range known to the tribe), "where he still lives." "The crystal rock" of Mrs. Parker, and the two quartz crystals mentioned to Mr. Howitt by a Wirajuri wizard, are no doubt derived from the quartz crystals of the wizards, whereby they are supposed to receive and hold their powers. Baiame, having still mightier powers, and being the source of theirs, is naturally credited with a larger quantity of the marvellous stone, glorified by Mr. Manning into a similitude with the throne of the apocalyptic version. It will be admitted that these are considerable divergences from $\mathrm{Mr}$. Manning's account, and that they lead to the suspicion that he did not fully understand the meaning of what he had heard. Concerning Bullimah and the "abode of the wicked" we require further information. In one of her stories Mrs. Langloh Parker narrates very interesting funeral rites and prayers for the dead. We.want to be assured whether these are usual, by means of an accurate description of the customary ceremonies; and that she does not give us. In the case referred to, Byamee is implored to "Jet in the spirit of Eerin to Bullimah. Save him, we ask thee, from Eleänbah wundah, abode of the wicked." But Eerin was changed into a small grey owl, to keep watch over his people and warn them of danger. On the whole, Mrs. Parker sufficiently corroborates . Mr. Manning to make a case for further inquiry, and that is all. It is by no means clear that they are both writing of the same tribe. I think, however, it will be conceded that the variations amply support my criticisms on Mr. Manning.

I cannot pursue Mr. Lang's remarks on Baiame or the other divinities any further. A few words must be devoted to the questions of morality. Mr. Lang is wise not to insist on his parallel of the first of the Kurnai precepts and "the First Commandment with promise." As to the second precept, "To share everything they have with their friends," he contests my interpretation that it refers merely to tribal 
regulations concerning the distribution of food. He says : "Mr. Howitt does not say so." Mr. Lang has overlooked the passage, for Mr. Howitt does in effect say it. In the very paper which gives an account of Mungan-ngaur he tells us: "The Jeraeil [the mysteries of the Kurnai] and the Kuringal [those of the Murring] resemble each other in being intended to impress upon the youths a sense of responsibility as men, to implant in them by means of impressive ceremonies the feeling of obedience to the old men, and to the tribal moral code of which they are the depositories, and to ensure that, before the youth is permitted to take his place in the community, join in the councils, and marry, he shall be possessed of those qualifications which will enable him to act for the common welfare, and not only to support himself and a wife and family, but also to contribute a fair share to the general stock of food, to which his relatives are entitled in common with himself." I If the mysteries are, as doubtless they are, traditional from a period long before money and tinned lobsters were known to the blackfellow, it is obvious that the precept must refer to the tribal regulations as to food. And, happily for $\mathrm{Mr}$. Lang's satisfaction, Mr. Howitt is here explicit upon the point. Nor is he explicit only upon this point. He includes a general account of the common purpose of the mysteries both of the Kurnai and the Murring tribes which vindicates my criticism of them. I do not deny the existence of $\phi i \lambda i a$ in Australian morals. What society could hold together without it? But the main purpose of the mysteries is different. It is discipline, the preservation of the social organisation; and that organisation is a savage one. If Mr. Lang merely meant that the blackfellows had "the elements of consideration for unprotected women, and of

' Journal of the Anthropological Institute, vol. xiv., p. 320. I had omitted to note the reference to this passage, and somehow could not put my finger on it in writing my criticism, though I searched severnl times, for the purpose of quoting it. 
regard for marriage," and that the resemblance of the foodrestrictions and so forth to Leviticus was that there were taboos in both, I can only say that the resemblance is hardly greater than that between Macedon and Monmouth, and that he expressed himself unfortunately by his parenthetical quotations, and his allegation that "much of the Decalogue and a large element of Christian ethics are divinely sanctioned in savage religion."

There are many more points in Mr. Lang's Reply to which I should like to refer. I must content myself, however, with inviting a careful comparison, by readers who are interested in the subject, of that reply with the chapters in The Making of Religion and my criticisms thereon. Such readers will not assume that contentions I have passed over in silence are not amenable to an effective rejoinder. I have been compelled to frame my observations for the most part in general terms; but I think they will apply to all the more important details discussed by Mr. Lang. We always read with pleasure and instruction what he writes. It would be impertinent in me to offer words of praise to a master of literary exposition and controversy, to whom the science of anthropology owes so much. His foregoing Reply, whether sufficient or (as I venture to think) not, displays all his entertaining skill and geniality. After all, I do not desire, and I am sure he does not desire, victory, but truth. "More facts and more careful criticism" are, as he says, what we want. In scientific inquiry a dialectic triumph may be a disaster. 